\title{
Mediakasvatusta kaikenikäisille
}

\author{
ANU MUSTONEN
}

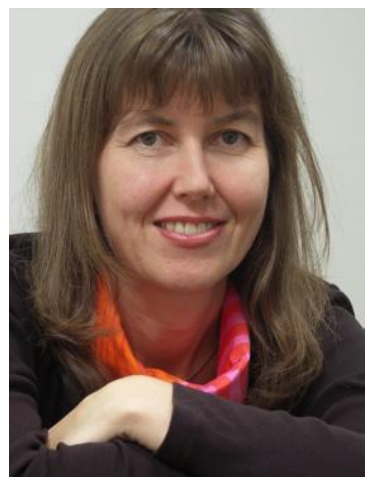

- Mediakasvatuksen tavoitteena on tuottaa osallistuvia, itseään sujuvasti ilmaisevia ja kriittisiä kansalaisia, jotka päivittävät jatkuvasti myös viestintäteknologista osaamistaan. Yksi keskeinen tehtävä onkin pienentää inmisiä eriarvoistavaa digitaalikuilua. Viestintäkasvatuksen kolmijako omaan ilmaisuun, kriittiseen tarkasteluun ja viestinnän rakenteiden ymmärtämiseen pätee myös mediakasvatukseen. Mediakasvatus vaatii jatkuvasti monimuotoisessa mediamaailmassa kasvatustalkoita, joissa kaikilla sukupolvilla on opetettavaa toisiltaan, kirjoittaa Anu Mustonen.

Digitalisoinnin myötä media on muuttunut joukkoviestimestä monimuotoiseksi tiedon, viihteen, asioimisen ja myös keskinäisviestinnän kanavaksi. Laajasti käsitettynä mediaksi voidaan lukea perinteisten viestimien lisäksi tietoverkot (internet, sähköposti), CD-rom-tuotteet (hypermedia, multimedia), digitaaliradio ja -televisio sekä osa matkapuhelinpalveluista. Vuorovaikutteinen tietokonemedia on tuonut mediakokemuksen psykologisesti uudelle, kokonaisvaltaiselle tasolle, yhdistäähän se tekstiä, kuvaa, ääntä, musiikkia ja muita tehokeinoja elämysvoimaisesti.

Passiivisesta vastaanottajasta on samalla tullut aktiivinen, vuorovaikutteinen viestijä. IImaisuvoimansa ja vuorovaikutteisuutensa vuoksi media myös muokkaa yhä vahvemmin tiedonhankintaa, asenteita, sosiaalista ja tunne-elämää, identiteettiä, maailmankuvaa, elämäntyyliä ja rytmiä. Viestintä- ja mediataidot ovat kiistämättä nykyajan kansalaistaitoja, joita kaikenikäisten tärkeää päivittää ja harjoitella. Mediakasvatus on koulutusala, josta ei tulla valmiiksi koskaan!

Teknologiset muutokset ulottuvat aina myös psykologiselle ja sosiaaliselle tasolle. Termit virtuaalitodellisuus, teleläsnäolo sekä immersio kuvaavat uusia, median välittämiä kokemuksellisia tiloja (ks. Mustonen, 2004a).

Immersio on samastumista voimakkaampi psykologisen eläytymisen kokemus, tunne siitä, että käyttäjä sulautuu mediakertomuksen sisään ja uppoutuu mediamaisemaan. Immersiokokemuk- sen aikana laitteet ja fyysinen ympäristö katoavat käyttäjän tietoisuudesta. Harvey ym. (1998) ovat osoittaneet, että vuorovaikutteisuus, useita aisteja yhdistävä stimulaatio ja dynaamiset tietokonenäytöt lisäävät median avulla synnytettyä immersiokokemusta. Tulevaisuudessa tietotekniikka on yhä sisäänsäsulkevampaa myös fyysisellä tasolla, kun laitteet kytkeytyvät elinympäristöömme upotetusti (ubiquitous computing). Japanissa lanseerattu ubiikkiyhteiskunnan käsite (ubiquitous society) kuvaa "kaikkialla läsnä olevaa verkkoyhteiskuntaa", jossa tietotekniikka on sulautunut osaksi arkipäiväämme.

Mediakasvatus vaatii jatkuvasti monimuotoisemmassa mediamaailmassa kasvatustalkoita, joissa kaikilla sukupolvilla on opetettavaa toisilleen. Teknologisissa taidoissaan lapset häikäisevät vanhempansa. Nuoret ottavat uudet teknologiat haltuunsa nopeasti, luovat itse uusia käytäntöjä ja sovelluksia sekä hyödyntävät median mahdollisuudet suvereenisti tiedon ja elämysten hankintaan, kommunikaatioon ja asioiden hoitamiseen.

Lapsilta ja nuorilta puuttuu kuitenkin elämänkokemuksen tuoma peilauspinta, johon suhteuttaa näkemäänsä ja kokemaansa. Jos lapset voivatkin perehdyttää vanhempiaan ja isovanhempiaan median käyttömahdollisuuksiin, aikuisia puolestaan tarvitaan median käytön pelisääntöjen tekemiseen ja kriittisten tulkintataitojen rakentamiseen. 


\section{Mediakasvatusta kaikenikäisille}

Mediakasvatuksen tavoitteena on tuottaa osallistuvia, itseään sujuvasti ilmaisevia ja kriittisiä kansalaisia, jotka päivittävät jatkuvasti myös viestintäteknologista osaamistaan. Viestintäkasvatuksen kolmijako omaan ilmaisuun, kriittiseen tarkasteluun ja viestinnän rakenteiden ymmärtämiseen (Falck \& Grönholm, 2004) pätee myös mediakasvatukseen. Mediataitoja on hyvä harjoitella median vastaanottajana, käyttäjänä ja tuottajana.

Euroopan eri maissa tehty vertailututkimus (Pasquier ym. 1998) osoitti, että digitaalinen media on lisännyt median privatisoitumista ja se virittää enemmänkin lasten keskeisiä kuin perheenjäsenten sosiaalisia suhteita. Lapset viettävät yhä enemmän aikaa median ja ikätovereidensa parissa, usein omissa huoneissaan ja perheiden yhdessäolon kustannuksella. Jo pelkästään se, että mediaa käytettäisiin yhdessä, toisi luontevia mediakasvatuksen ja vuorovaikutuksen tilaisuuksia perheenjäsenten kesken.

Arkisimmillaan mediakasvatus onkin tietokoneen käyttövuorolistoja, mainosten kyseenalaistamista, kaukosäätimen herruudesta kiistelemistä, kännykän käytön opastusta ja elokuvien ikärajojen noudattamista. Keskustelu pelottavista lööpeistä tai uutisvalinnoista ovat kaikki esimerkkejä mediakasvatuksesta, samoin keskustelu siitä, pitääkö muotileluja ostaa koko sarja, niin kuin mainos kehottaa.

Pienimmät lapset tarvitsevat suojaa ja rajoituksia säästyäkseen kehitykselle vahingollisilta mediasisällöiltä. Kohti kouluikää tultaessa, tunteiden hallinnan ja ymmärryksen lisääntyessä, yhä tärkeämmäksi tulee mediakasvatus, joka vahvistaa ja voimauttaa median käyttäjää suojaten riskivaikutuksilta. Nykypäivänä mediakasvatus onkin koko elämän pituinen prosessi: osatakseen käyttää mediaa tiedon hankintaan, viihtymiseen ja asioiden hoitamiseen täytyy jokaisen seurata teknologista kehitystä, opetella uusien ilmaisukanavien käyttöä ja ennen kaikkea ylläpitää itsenäistä ja kriittistä suhdetta median sisältöihin.

Koulussa viestintä- ja mediataidot ovat eräs valtakunnallisen opetussuunnitelman aihealue, jota kukin opettaja soveltaa opettamansa aineen puitteissa. Mediakasvatuksella ei kuitenkaan ole vakiintunutta paikkaa kouluopetuksessa. Painokkaimman roolin mediakasvatuksessa ovatkin ottaneet kansalaisjärjestöt ja vanhempainyhdistyk- set, jotka tarjoavat koulutuksia aikuisille kuten vanhemmille ja nuorten kanssa toimiville. Samoin useissa kirjastoissa, kansalaisopistoissa sekä osana kuntien ja seurakuntien nuorisotyötä opastetaan kaikenikäisiä median käyttömahdollisuuksiin ja median vastuulliseen käyttöön. Myös media itse kuten sanomalehdet on ottamassa yhä enemmän vastuuta mediakasvatustyössä. Esimerkiksi Yleisradion Mediakompassi-opetusohjelmasarja tarjoaa omat versionsa opettajille, vanhemmille ja nuorille.

Aikuisten mediakasvatuksessa kysymys on lähinnä kuluttajavalistuksesta ja perehtymisestä uusiin mediapalveluihin, tietoturvaan ja netikettiin sekämediaa sekämainosalaa koskevaan sääntelyyn kuten kuvaohjelmien ikärajoihin. Myös perustiedot median ja mainosten mahdollisista vaikutuksista sekä median keskeisten tuotantoja omistusrakenteiden tuntemus auttavat kriittisen otteen löytämisessä. Erityisen tärkeää olisi, että kasvattajat ja vanhemmat seuraavat ja yrittävät hahmottaa nuorten suosimia mediapalveluja, jotta he pystyvät olemaan lastensa tukena myös mediankäytössä. Nykyaikaisiin mediataitoihin kuuluu päivittää viestintäteknologian ja verkkoviestinnän edellyttämät ilmaisutaidot. Tähän kaikkeen opettaja löytyy useimmiten kovin läheltä: omista tai naapureiden jälkikasvusta. Informaatiotulvan keskellä tarvitaan myös tiedonhallinnan, -jäsentelyn ja säilömisen taitoja sekä kykyä kohdentaa omia viestejä järkevästi. Tässä on kaikenikäisillä harjoittelemisen paikkoja.

Vanhemmuuden tukeminen media-asioissa perustuu Euroopassa enemmän valistuksellisiin ja mediakasvatuksellisiin keinoihin kuin sensuuriin tai teknisiin ratkaisuihin kuten suodatin- tai esto-ohjelmiin. Yhdysvalloissa televisio-ohjelmien suodattamiseen käytetään yleisesti "sensuurisirua", mutta internetin suodatinohjelmia vanhemmat käyttävät sielläkin satunnaisesti: joka kolmas perhe turvautuu suodatinohjelmiin ja ohjelmien käytöstä viimeisen vuoden aikana oli luopunut 5 prosenttia (Mitchell ym. 2005). Näin, koska toistaiseksi tarjolla ei ole kovin kehittyneitä ja luotettavia esto-ohjelmia.

Mediakasvatus voi olla paitsi mediataitojen kartuttamista, myös median itsensä valjastamista oppimiseen ja tiedonhankintaan. Vuorovaikutteinen ja immersiivinen media on motivoiva oppimisympäristö, joka palvelee parhaimmillaan tutkittaessa prosesseja ja havainnollistettaessa mutkikkaita kokonaisuuksia visuaalisesti. Tietotek- 
niikan avulla voidaan koota, jäsennellä ja raportoida havaintoaineistoa ja simulaatioiden avulla harjoitella asioita, jotka olisivat oikeassa elämässä vaarallisia ja kalliita kuten lääketieteelliset operaatiot tai lentämisharjoitukset. Tietotekniikan vetovoimaisiksi osoittautuneista viihdesovelluksista, erityisesti peleistä, olisi paljon opittavaa luotaessa kiinnostavia oppimisympäristöjä kaikenikäisille (Kankaanranta ym. 2004).

\section{Suosikkimedia tarjoaa seuraa ja kontakteja}

Median käytöstä yhä suurempi osa sijoittuu digitaalisiin ympäristöihin, erityisesti internetiin. Sosiaalisen kanssakäymisen moninaiset mahdollisuudet selittävät internetin palvelujen suuren vetovoiman, tarjoaahan verkkoviestintä helpon ja tarvittaessa anonyymin keskustelukanavan. Verkossa kontaktinotto vieraisiin inmisiin on helpompaa kuin nokatusten, ja tällöin arkajalkakin voi luoda julkista elämää panematta koko persoonaansa alttiiksi. Internet on noussut myös tärkeäksi sosiaalisen tuen lähteeksi. Shepherd ja Edelmann (2005) ovat havainneet, että sosiaalisesti ahdistuneille inmisille netti tarjoaa reaalimaailmaa helpomman kontaktipaikan. Monille sosiaalisista peloista kärsiville netti on tärkeä keino hoitaa sosiaalisia suhteita.

Ben-Zèevin (2004) mukaan verkkoviestinnässä syntyvät suhteet tarjoavat paljon tunteita ja synnyttävät emotionaalista avoimuutta - mutta samalla mahdollistaen myös yksityisyyttä, anonyymisyyttä ja psykologista etäisyyttä. Reaalielämän suhteissa taas on toisin päin, anonyymisyys on mahdotonta ja tunteet usein kätketympiä. Aaron rinnastaa netin ja mielikuvituksen: molemmat luovat tunteita ja antavat mahdollisuuden yksityisyyteen.

Digitaalisen median peliympäristöt ovat edelleenkin miehistä maailmaa. Niin pelaajat kuten pelien hahmot ovat viime aikoihin asti edustaneet enimmäkseen miehiä. Naiset ovat peleissä vähemmistönäja mieshahmoja useammin seksualisoiden esitettyjä (Ivory, 2006). Internet on kokonaisuutena kuitenkin tasa-arvoistunut. Tytöt ja naiset ovat löytäneet internetin palvelut erityisesti seuraelämää rikastuttavien palvelujen myötä. Esimerkiksi viime vuosien suursuosikissa, kuvagallerioissa, tytöt ja nuoret naiset muodostavat valtaenemmistön (Peura, ym. 2006).

Eri-ikäisten suosimat keskustelupalstat eli cha- tit tarjoavat rupattelua nimimerkin suojissa. Chat on reaaliaikainen ja viestit katoavat nopeasti bittitaivaaseen. Keskustelupalstoille viestit jäävät pidemmäksi aikaa kaikkien luettavaksi. Ominaista näille molemmille on itsen valikoiva esittäminen, sosiaalisten suhteiden helppo säätely ja rooleilla leikitteleminen.

Samoin kuin mainostajat, myös modernit kasvattajat ja valistajat ovat siellä, missä kohderyhmäkin eli yhä useammin verkossa. Esimerkiksi huumevalistajat ovat löytäneet nuorten suosimat ympäristöt kuten Habbo hotel -palvelun, joka on chatin ja nettipelin risteytys. Myös mielenterveys- ja nuorisotyötä tekevät ovat paikalla nettipalveluissa. Nettikeskustelu on nuorelle helppo tapa kohdata nuorisotyöntekijöitä ja puhua asioista, joita ei ikinä kertoisi kasvotusten. Moniin nuorten suosimiin palveluihin on ilmestynyt myös valitussivut vanhemmille, sillä sivujen ylläpitäjät toivovat vanhempien perehtyvän paremmin lastensa nettikäyttäytymiseen.

Vanhempi polvi on vasta löytämässä internetin pikaviestimet kuten "Mesen" eli Messengerin ja Skypen, jotka keventävät puhelinlaskuja sallien reaaliaikaisen yhteydenpidon joko kuvayhteyden kera tai ilman sekä tuttujen että vieraiden kanssa. Pikaviestimien avulla voidaan myös jakaa linkkejä ja tiedostoja. Ajallemme tyypillinen palvelu ovat internetin kuvagalleriat, jotka keskittyvät ulkonäköön ja julkisuuden tavoitteluun. Jo yli puoli miljoonaa suomalaista nuorta ja nuorta aikuista on perustanut nettiin kuvagallerian, joka tarjoaa areenan julkiseen esittäytymiseen ja palautteen saamiseen omasta ulkonäöstä. Gallerioissa suurin osa nuorista on liittynyt erilaisiin yhteisöihin, löytänyt uusia ystäviä ja jopa seurustelukumppaneita (Peura, ym. 2006).

Mediakasvatuksen tärkeä tehtävä on tuoda esille, että nettipalvelut ovat useimmiten julkisia eivätkä keskinäisviestintää. Tämän hahmottaminen näyttää olevan yhteinen ongelma eri ikäpolville. Jos eivät nuoret ymmärrä, eivät välttämättä heidän vanhempansakaan tunnu käsittävän, että netti on maailmanlaajuinen media. Moni haluaa kontrolloida oman mahdollisen esiintymisensä paikallislehdessä, mutta voi laittaa nettiin hyvinkin uskaliaan poseerauskuvan. Näistä onkin tullut kuvagallerioiden ongelma, joka pahimmillaan houkuttelee palveluun pedofiilejä ja muita häiriintyneitä aikuisia.

Mediamarkkinoita hallitsevien viihdesovellusten lisäksi on kehitelty myös hyötypelejä (se- 
rious games), jotka hyödyntävät tietokonepelien vetovoimaisia piirteitä auttaessaan oppimaan, havainnollistamaan tai vaikkapa harjoittelemaan erilaisia taitoja simulaation keinoin (katsaus aiheeseen, ks. Mustonen, 2004b). Hyötypelejä on kehitelty myös tunne-elämän kehityksen tukemiseen, erityisryhmien kuntouttamiseen, psykoterapeuttisiin sekä lääketieteellisiin tarkoituksiin. Tietokonepelien immersiivisyys voidaan valjastaa vaikkapa vaikeasti sairaiden kivun lievittämiseen. Kiinnostava pelimaailma sieppaa potilaan huomion ja motorisen aktiivisuuden, jolloin kiputuntemukset jäävät taka-alalle.

\section{Riippuvuus: kun media on liiankin palkitseva}

Yhä useampi on löytänyt internetin mielialoja kohentavat palvelut ja käyttävää nettiä aktiivisesti kielteisten tunnetilojen kuten ikävystymisen, ahdistuksen ja masennuksen lieventämiseksi. Varsin yleistä on myös netin käyttö seksuaalisen virityksen lisäämiseksi (Quayle ym. 2006). Mitä suuremmat mahdollisuudet virtuaalitodellisuudella on kohentaa käyttäjän mielialaa, sitä palkitsevampi ja edelleen myös addiktoivampi mediasuhteesta voi muodostua.

Kuten kaiken mieluisan ja palkitsevan toiminnan, myös mediankäytön haasteena on harrastuksen pitäminen kohtuullisena (Mustonen, 2001). Erityisesti myönteisten sosiaalisten kontaktiensa vuoksi digitaalinen media tuottaa riippuvuutta aivan eri tapaan kuin perinteinen media. Riippuvuudesta eli addiktiosta voidaan puhua, jos netin tai pelien käyttö on hallitsematonta ja pakonomaista ja jos omat voimat eivät riitä tietokoneen sammuttamiseen. Elämästä katoaa rytmi, kun addiktiosta kärsivä unohtaa syödä ja nukkua. Oikeat, reaalielämän ystävät häviävät.

Koukkuun jäämiselle altistavat vuorovaikutteiset verkkoviestinnän muodot, jotka tarjoavat reaaliaikaisia sosiaalisia kontakteja. Addiktion taustalla on usein sosiaalisia ongelmia ja ystävien puutetta: maailma potkii päähän, mutta virtuaalinen vuorovaikutus palkitsee ja tarjoaa hyväksyntää. Griffiths (1999) painottaa, että tietokone on suuressa osassa riippuvuustapauksia pelkästään väline. Ensisijainen riippuvuus voi kohdistua ihmissuhteisiin, sosiaalisten suhteiden rakentamiseen, roolipelien kautta luotuun minäkuvaan tai virtuaalimaailman tuottamiin tunnepohjaisiin elämyksiin.
Seksisisällöt ovat nettimaailmassa yhä yleisempiä (Peter \& Valkenburg, 2006). Yksi yleistyvä nettiriippuvuuden muoto onkin nettiseksiriippuvuus (cybersex compulsives) jonka ennustajia ovat masennus, ahdistuneisuus ja vaikeudet rakentaa läheisiä suhteita reaalielämän partnereiden kanssa. Useimmille keskusteluryhmät ja pelaaminen ovat ylimääräistä ajantäytettä, mutta monille ne ovat myös aitojen ihmissuhteiden korvike tai rempallaan olevien ihmissuhteiden kompensaatiota.

Nettiriippuvuuden diagnostiikkaa ja hoitoa on tehty erityisesti Aasian maissa (Rong \& Yong, 2005; Qing-Xin ym. 2005; Bi ym. 2005), Bi ym. (2005) havaitsivat, että addiktio on yleisempää amerikkalaisten opiskelijoiden parissa kuin kiinalaisten, mutta kiinalaisella kampuksella puolestaan yleisempää kuin taiwanilaisella. Suomalaisten nettiriippuvuudesta ei ole toistaiseksi tutkimustietoa. Kulttuurista riippumatta pojat ovat tyttöjä enemmän riskissä addiktoitua. Heikot sosiaaliset taidot ja persoonallisuuden piirteistä elämyshakuisuus (Qing-Xin ym. 2005), neuroottisuus ja matala ekstraversio (Bi ym. 2005) näyttävät olevan yhteydessä riippuvuuden kehittymiseen.

Vaikka netin suurkäyttäjä ei kärsisikään varsinaisesta riippuvuudesta, virtuaalimaailman helppoihin sosiaalisiin suhteisiin tottunut voi kohdata haasteita elävän elämän ihmissuhteissa. Netissähän sosiaalisiin suhteisiin antautuminen on riskittömämpää, sillä sitoutumisen tason voi itse päättää ja lopettaa suhteen ilman repiviä jälkipuinteja. Oikeassa elämässä tarvittavia sosiaalisia taitoja opitaan parhaiten tavallisissa arkipäivän tilanteissa, joissa toisen tunteet on pakko ottaa huomioon päätöksiä ja valintoja tehtäessä, ristiriitoja ratkaistaessa ja vastavuoroisessa ajatusten ja näkemysten vaihtamisessa.

\section{Vertaistuki verkkoviestinnän voimavarana}

Internet voi yhä enemmän toimia nuorten tärkeänä elämänalueena ja vertaistuen väylänä, media tarjoaa paljon mahdollisuuksia myös vanhemmuuden tukemiseen. Verkkoviestintää käytetään yhä enemmän perheiden, koulujen ja muiden yhteisöjen toiminnan verkottamiseen (Mustonen \& Pulkkinen, 2003). Julkiset palvelut kuten neuvolat sekä kasvatuksen ja lastensuojelun piirissä toimivat kansalaisjärjestöt tarjoavat monenlais- 
ta vertaistukea sekä asiantuntija- ja keskusteluapua. Uusi teknologia antaa mahdollisuuden vertailla ja jakaa kokemuksia ja kysyä neuvoa silloin, kun kullekin parhaiten sopii - tosin vain sellaisissa kysymyksissä, jotka eivät vaadi asiantuntijan vastaanotolla käyntiä. Näin voidaan saada nopeasti tukea pienimuotoisiin terveys- tai kasvatuspulmiin ja säästää resursseja asioihin, jotka vaativat paneutuneempaa, henkilökohtaista kohtaamista.

Ruotsalaisen Sarkadin (2005) mukaan erityisesti kasvatuksen alueella internetin vertaistuki on yhä halutumpaa. Digitaalinen kuilu (digital divide) on vähentynyt eli sosioekonominen asema ei vaikuta internetin käyttöön enää kovin paljon. Sarkadin tutkimus osoitti, että vertaistukipalstoilta saatu tuki kasvatuskysymyksissä oli suurinta nimenomaan ilman partneria asuvien keskuudessa sekä vähemmän koulutettujen ja matalatuloisten parissa. Toisten vanhempien tuki osoittautui vanhemmille jopa tärkeämmäksi kuin asiantuntijoiden neuvot. Kävi myös ilmi, etteivät isät ole Ruotsissakaan innokkaita lastenkasvatuspalstojen käyttäjiä tai vertaistuen hakijoita. Edes miehien muuten suosima teknologiaympäristö ei siis tee lastenhoito- ja kasvatuskeskustelua houkuttelevaksi miehille.

Samansuuntaisia tuloksia on saatu Suomessakin tutkittaessa, miten tietoverkkoja voitaisiin hyödyntää vielä enemmän perheiden ja sukupolvien välisessä yhteydenpidossa. Kyseltäessä viestintävälineiden vaikutuksia ja mahdollisuuksia perheen sisäisessä viestinnässä isät esittivät eniten kielteisiä arvioita; äidit näkivät enemmän myös mahdollisuuksia (Siitonen ym. 2002).

Perheiden ja sukulaisten hajaantuessa eri paikkakunnille mediaa voitaisiin hyödyntää enemmän. Lastenlasten yhteydenpito usein kaukana asuviin isovanhempiin rikastaisi niin lasten kuin isovanhempienkin elämää, antaisi perspektiiviä oman suvun historiaan ja luotaisi laajempaa näkemystä maailmasta (Harwood, 2000). Isovanhemmat taas voisivat pysyä perheensä arjessa ja elämässä kiinni seuraamalla lapsensa kehittymistä kasvun kansion avulla, nähdä internetistä lapsen kuulumisia ja aikaansaannoksia sekä jutella tämän kanssa sähköpostissa tai keskusteluryhmissä

Mahdollisuus anonyymisyyteen sekä reaaliaikaiseen vertais- ja keskusteluapuun ovat verkkopalvelujen kiistattomia vahvuuksia. Tekstistä vuorovaikutuksen välineenä puuttuu kuitenkin välitön palaute ja ei-verbaalisen viestinnän muodot. Nettipalvelut jättävät vastausten lukijan omille tulkinnoille paljon tilaa, jolloin myös väärinkäsitysten riski on suuri.

\section{Päätelmät: Mediasta kasvatuskaveri}

Media voi olla kasvatuksen väline, oppimisen kanava ja myös kasvatuksen kohde. Mediakasvatusta tarvitaan, jotta voitaisiin lisätä mediasta saatavaa iloa ja hyötyä sekä vahvistua median riskejä vastaan. Koska median riskikäyttöä, kuten riippuvuutta, ennustavat heikot sosiaaliset taidot, myös ongelmien ennaltaehkäisyssä tärkeäksi nousevat keinot, jotka edistävät reaalielämän vuorovaikutusta, sosiaalisia taitoja ja myös median käytön sosiaalisuutta perheissä ja kodeissa

Mediateknologioiden ja palvelujen muuttuessa on asiantuntijoidenkin vaikeaa pysyä kehityksen vauhdissa. Mediataitojen ja erityisesti median uusien käyttömahdollisuuksien löytämisessä lapset ja nuoret toimivat usein parhaina opastajina vanhemmille sukupolville. Aikuisten tehtävä puolestaan on tukea nuorempia kriittisten tulkintataitojen hankkimisessa ja median sisältöjen kyseenalaistamisessa.

Mediakasvatuksen eräs tehtävä on digitaalikuilun pienentäminen niin, että kaikki pääsevät osalliseksi viestintäteknologioihin liittyvistä kansalaistaidoista. Tytöt ja pojat, naiset ja miehet ovat käyttäjinä löytäneet digitaalisen median palvelut melko tasa-arvoisesti. Mediasisältöjen tuottajat ovat edelleenkin enemmän miehiä, joten naisnäkökulma olisi tervetullut lisä alan tasapainoiseen kehitykseen. Poikkeuksena ovat kasvatuksen alan yhteisöt, joihin miehet ja isät voisivat rohkaistua enemmän tuomaan miesnäkökulmaa.

Mediaympäristön vetovoima tuo esiin myös kohtuullisuuden ihanteen. On tasapainoteltava toisaalta digitaalisen kuilun estämiseksi niin, että verkkopalvelut olisivat kaikkien saatavilla riippumatta asuinpaikasta, sosioekonomisesta asemasta tai sukupuolesta. Toisaalta olisi huolehdittava, ettei median käyttö ole yltiöpäistä ja todellisuutta pakenevaa, jottei mediamaailmasta tulisi riippuvuutta ja sosiaalisista suhteista syrjäytymistä tuottava virtuaalimaailma.

Media on motivoiva ja myönteisesti latautunut toimintaympäristö, joka tarjoaa paljon vielä hyödyntämättömiä mahdollisuuksia kasvatuk- 
seen, viestintään ja vaikuttamiseen. Erityisesti anonyyminä ja reaaliaikaisesti tarjolla oleva vertaistuki esimerkiksi kasvatuksen kysymyksissä on digitaalisen median tärkeä voimavara. Myös median viihteelliset palvelut, seikkailu virtuaalimaailmassa tai luoviminen tiedon ja mainosten tulvassa on sitä antoisampaa, mitä itsenäisemmin käyttäjä hallitsee median ja mitä vähemmän media hallitsee inmistä.

\section{Lähteet}

Ben-Ze`ev Aaron (2004). Love Online: Emotions on the Internet. Cambridge University Press.

Bi, Y., Su, W.-I., Sun, Y.-F., Cau, H. \& Wang, J.-P., (2005). Behavioral charasteristics of Internet addicted students in college. Chinese Journal of Clinical Psychology, 13, 2, 170-172.

Falck, R. \& Grönholm, I. (2004). Mahdollisuuksien media - Viestintä ja mediataito opetuksessa. Teoksessa Loukola, M.-L (toim.) Aihekokonaisuudet perusopetuksen opetussuunnitelmassa. s. 51-55. Opetushallitus.

Griffiths, M. (1999) Internet addiction: Fact or fiction? Psychologist, 12, 5, 246-250.

Harvey, M.L., Loomis, R.J., Bell, P.A. \& Marino, M. (1998). The influence of museum exhibit design on immersion and psychological flow. Environment and Behaviour, 30, 5, 601-627.

Harwood, J. (2000). Communication media use in the grandparent-grandchild relationship. Journal of Communication, Autumn, 56-74.

Ivory, J.D. (2006) Still a Man's Game: Gender representation in online reviews of video games. Mass Communication and Society, 9, 1, 103-114.

Kankaanranta, M. , Neittaanmäki, P. \& Häkkinen, P. (toim. 2004). Digitaalisten pelien maailmoja. Koulutuksen tutkimuslaitos ja Agora Center. Jyväskylän yliopisto.

Mitchell, K., Finkelhor, D. \& Wolak, J. (2005). Protecting youth online: Family use of filtering and blocking software. Child Abuse \& Neglect, 29, 7, 753-765.

Mustonen, A. (2001) Mediapsykologia. WSOY.

Mustonen, A. \& Pulkkinen, L. (2003). Sosiaalinen alkupääoma ja tietotekniikka. Tulevaisuusvaliokunta. Teknologian arviointeja 14.
Eduskunnan kanslian julkaisu 1/2003.

Mustonen, A. (2004a). Etäällä läsnä - lähellä etänä-läsnäoloa lapsiperheissä. Teoksessa Heinonen, J., v. Hertzen, G. \& Kuusi, O. (toim.) Nyt on ennen huomista. s. 33-40. Ekosäätiö.

Mustonen, A. (2004b). Joulupukilla sikapeli säkissä. Duodecim, 120, 23, 2805-2814.

Pasquier, D. (2002). Media at home: domestic interactions and regulation. Communication Abstracts, 25, 2, April.

Peter, J. \& Valkenburg, P.M. (2006). Adolescents' exposure to sexually explicit material on the Internet. Communication Research, 33, 2, 178-204.

Peura, J. Mikkola, H., Oinas, M.-M., Tuominen, S. \& Mustonen, A. (2006). "Hätäilette liikaa, kyllä me nuoret osataan" Netin kuvagallerioiden ilot ja ongelmat. Mannerheimin Lastensuojeluliitto. www.mll.fi/viisaastiverkossa

Philaretou, A. G. \& Mahfouz, A.Y. \& Allen, K.R. (2005). Use of Internet pornography and men's well-being. International Journal of Men's Health. 4, 2. 149-69.

Rong, Y., Zhi, S. \& Yong, Z (2005). Comprehensive intervention on Internet addiction of middle school students. Chinese Mental Health Journal, 19, 7, 457-459.

Quayle, E., Vaughan, M. \& Taylor, M. (2006). Sex offenders, Internet child abuse images and emotional avoidance. Aggression and Violent Behavior, 11, 1, 1-11.

Qing-Xin, S., Rong-Gang, Z., \& Yan, G. (2005) Internet addiction disorder and sensation seeking of middle school and high school students. Chinese Mental Health Journal, 19, 7, 453-456.

Sarkadi, A. (2005) Socially unbiased parenting support on the Internet: A cross-sectional study of users of a large Swedish parenting website. Child Care, Health and Development, (31), 1, 43-52.

Shepherd, R.-M. \& Edelmann, R.J. (2005) Reasons for Internet use and social anxiety. Personality and Individual Differences, (39), 5, 949-958.

Siitonen, (2002) Tieto- ja viestintätekniikka ja yhteydenpito yläasteikäisten perheissä. Tutkimusraportti. Perheportaali-projekti. Jyväskylän yliopisto. 